\title{
訪問看護師の仕事負担感や就業継続意思と業務特性との関連
}

\author{
光本 いづみ1, 松下 年子'2,大浦 ゆう子3
}

1產業医科大学 産業保健学部 第二看護学講座

2 埼玉医科大学 保健医療学部 看護学科

3 国際医療福祉大学大学院 医療福祉学研究科 保健医療学専攻 看護学分野

要旨：訪問看護師の仕事負担感や就業継続意思と訪問看護の業務特性を明らかにし た。対象は福岡県内の訪問看護ステーションに勤務する看護師で, 自記式質問 紙調查を実施した。その結果，下記の事柄が明らかになった。「就職前に考え ていた仕事内容と実際との相違」「訪問以外の仕事の多さ」「判断を必要とす る場面の多さ」「複雑な看護技術の多さ」を感じている人ほど仕事の負担感を 大きいと考え，「ステーションの将来性」「看護師の人数」「賃金」について肯 定感を持つ人ほど仕事の継続意思を持っていること，また，訪問看護師の就業 意欲向上のために, 管理者が労務管理の意識を高めることやリアリティショッ クへの対策として体系的・系統的継続教育の実現を図る環境を整えることも継 続意思を持つことの一助となることが示唆された．

キーワード：訪問看護師, 業務特性, 仕事負担感, 就業継続意思.

(2007 年10月26日 受付, 2008 年4 月3 日 受理)

はじめに

我が国では少子高齢社会が進行し，在宅医 療・在宅ケアはますます重要なサービスとなっ ている，その中心的立場にある訪問看護師へ の社会的要請および期待は増大傾向にあり， 対象が小児から高齢者, 虚弱・病弱者・重複障 害者など多岐に渡ること，また看護を提供す る場が在宅であるという特殊性から, 訪問看 護特有の専門性が求められている。ささらに複 合的な課題解決能力や状況に即応した倫理的 判断・意思決定能力などの専門的能力も切実 に問われてきており，訪問看護師の質的问上
が望まれている。しかし，訪問看護師の離職 率は病院勤務の看護師より高いという報告が あり [1], 訪問看護ステーションには, 病院で の看護経験 (以下, 病院看護とする)のある看 護師が再就職の場として選択することの多い 職場であることから考えると矛盾した状況が 存在している。そそのことについて胡 [2]は訪 問看護には病院看護と異なる業務の特性があ り, 病院看護を経験した看護師は, 訪問看護を はじめて「人間関係の形成」「社会資源の活 用」「個人の責任の重さ」などに病院看護との 違いを経験し，病院看護の経験があるがため に生じる葛藤も存在すると述べている，その 
ため, 病院看護の看護師が考える訪問看護と 実際の訪問看護業務には相違があり，訪問看 護をはじめた看護師にリアリティショックが 生じ, 離職や喪失感へ繋がっている訪問看護 師が少なからず存在していることが推測され る.

看護職の職場選びに関する看護職員実態調 查によると [3], 就業意識を支えるものは 1 ，労 働条件, 2 .労働環境, 3 .働き甲斐の3つであり， 求職中の看護師が職場を選ぶ上で重視するこ とは,「納得いく看護ができる」「キャリアアッ プに繋がる」「専門性を向上させられる」こと だという。つまり看護師のこれらのニーズ (職務満足) が実現できるような労働条件や 労働環境を組織が整備し看護師の働き甲斐を 高めるようサポートすれば, 組織はより優れ た人材を集めることが可能になる。さらに 訪問看護師の職務定着を促進し，かつ優れた 人材を定着させる組織の支援として鹿毛ら [4]は，訪問看護師の達成感やコミュニケー ションを重視した職場風土，ゆとりある環境 や労働条件, 訪問看護師の専門性や自律を高 めることが重要であると述べている。また Cherniss[5]は職場である組織と從業員の関係 から，仕事の達成基準は従業員個人にゆだね るのではなく、組織として明確化した上でプ ログラムを作成し自己効力感を高める支援が 必要であると述べている。またTeri A Murrai [6]は,病院から在宅看護へ移行した看護師 が, 最初の6 か月間に経験するストレスにつ いてインタビュー調査した結果, 組織による オリエンテーションやその後の教育プログラ ムによって, 看護師の円滑な在宅看護への意 識変化が容易になったと報告している。これ らの先行研究に扔いて, 従業員のスムーズな 職務定着を可能にするのは, 職場の組織的な 取り組みや具体的なプログラムであることが 示されている。組織とはいえ訪問看護ステー ションは小規模事業所が多くを占めるため, 職場全体としてこの課題に取り組んでいく 必要がある。そのためにはまず, 訪問看護師
の訪問看護の業務特性に対する認識, 仕事負 担感などの詳細を明らかにすることが望まれ る。ささらに業務特性のうち, 労務管理に関古 る就労者の評価と彼らの就業継続意向および 仕事負担感が大きいと認知している業務内容 を抽出することにより，訪問看護師がより高 い職務満足と専門的能力をもって, 訪問看護 という仕事にコミットメントできるような環 境および体制を整備する具体的方策について 示唆を得ることができる。

本研究では, 訪問看護師の仕事負担感や就 業継続意思は訪問看護の業務特性とどのよう な関連を持つのかを明らかにすることを目的 に福岡県内の訪問看護ステーションに勤務し ている訪問看護師を対象に実態を調査した。

\section{用語の定 義}

本研究で使用する用語を以下のように定義 する。

1. 仕事負担感：仕事を過重に感じること

2. 就業継続意思：現ステーションにこだわら ず,訪問看護の仕事を継続していこうとい う気持ち

3. 業務特性：その仕事だけが有する, 他と異 なった特別な性質(労務管理，業務内容を 含む)

4. 労務管理: 労働者の使用を合理化し生産性 を高めるために訪問看護ステーションの 管理者が行う人事・福利厚生・教育・労 働組合対策などを含む管理

5. 業務内容: 訪問看護師が行う業務全般

6.リアリティショック：現実が理想とかけ離 れていることに衝撃を受けることをいう。

\section{対象と方法}

独立行政法人福祉医療機構が運営する福祉 保健医療ならびに介護保険や障害者福祉サイ 卜(WAM NET)に登録されている福岡県内の 全訪問看護ステーションに勤務する管理者お 
よび常勤・非常勤看護師227 カ所1340 名を対 象とし, 平成 18 年6 月20日〜 月 31 日の間, 5 名の訪問看護師に対するプリテストを経て作 成した無記名オリジナルの自記式質問紙を用 いて調査した。調査依頼書と質問紙は対象の 訪問看護ステーションへ就労している訪問看 護師数分をまとめて郵送し, 回収については, 回答者が記入済みの質問紙をそれぞれ密封 し，それらを各ステーション管理者が収集し て返送して頂くように依頼した。

質問紙は，鹿毛ら [4], Cherniss[5], Teri A Murrai［6]により報告された諸所見を参考に して独自に作成し，現在就業中のステーショ ンおよび事業内容について看護師自身がどの ように評洒しているのかを回答する形式とし た，この質問紙はクロンバック a .735であっ た。

\section{1. 基本的属性}

性別, 年齢, 一般学歴, 看護学歴, 所持免許, 職位, 勤務形態, これまでに経験した職場, 一 週間あたりの訪問件数, 年収, 健康状態, 就職 理由, 現勤務経験年数, 看護経験年数, オン コール当番回数, 当番時の出勤回数

\section{2. 訪問看護の仕事負担感}

現在就業中の訪問看護ステーションで行っ ている業務について，仕事内容は身体的・精 神的に負担が大きいかという設問に対し，上 記と同じく「そう思う」「どちらかといえば そう思う」「どちらかといえばそう思わない」 「そう思わない」の4 選択肢から一肢選択する 形にした。

\section{3. 訪問看護師としての就業継続意向}

現職場に関わらず訪問看護の仕事を今後も 継繶しようと思うか否かについて、「できるだ け続けたい」「しばらくは続けたい」「機会が あれば他の仕事に変わりたい」「ぜひ他の仕 事に変わりたい」「わからない」の5 選択肢か ら一肢選択する形にした。
4. 訪問看護ステーションの労務管理および業 務内容

現在就業中のステーションの労務管理に関 する設問は以下のようにした１）ステーショ ンの将来性がある,2）経営理念が明確であ る，3）上司の管理がうまくいっている,4）全 体として職場は働きやすい，5）人数は足りて いる，6）賃金は仕事内容に見合っている，7)休 日を決める自由度がない,8）定時に帰れない ことが週に2 回以上ある,9)昼休みが45 分以 上とれる，10）希望する研修に参加できる，の 10 項目である。業務内容に関する設問は以 下のように設定した，1）仕事内容は就職前に 考えていたことと違う，2）訪問以外の任され ている仕事が多すぎる,3）学ばないといけな いことが多くある，4）判断を必要とする場面 が多すぎる，5）医療処置・複雑な看護処置が 必要とされている，6）自分自身の病気やけが などが心配である，7）利用者に医療事故が起 こるのではないかと不安,8）ケアに対して充 実感がある，の8 項目である，回答は，「そう 思う」が1 点,「どちらかといえばそう思う」 が2点,「どちらかといえばそう思わない」が3 点「そう思わない」が4点とした。

\section{5. 分析方法}

デー夕解析にはSPSS12.0J for Windows を用 いた。まず，すべての質問項目に対する記述 統計を行いその後,「仕事負担感と業務内容」 および就業継続意思と労務管理」との関連を Mann-Whitney- $U$ 検定にて分析した，なお，仕 事負担感は『仕事内容は身体的・精神的に負 担が大きいと思うか』の問いを「そう思う」 「どちらかといえばそう思う」を大きいと思 う群，「どちらかといえば思わない」「思わな い」を大きいと思わない群の 2 群とし, 就業継 続意思は「できるだけ続けたい」「しばらく続 けたい」の就業継続群と,「機会があれば他の 仕事に変わりたい」「ぜひ他の仕事に変わり たい」の就業非継続群の2 群とした. 
6. 倫理的配慮

質問紙は無記名とし, 対象者への調查依頼 書には，調査協力の同意・非同意は自由であ ること、データの取り扱いにおいて個人を特 定しないこと, 個人情報の取り扱いには細心 の注意を払うことなどを明記し，さらに，調査 票の記入・返送をもって研究への同意を得た とみなす旨も加えた。

\section{結果}

\section{1. 対象者の概要}

返送された質問紙は1294 名中319 名(回収 率 $24.6 \%$ ）で項目ごとの有効回答数は268 名 (20.7\%) 319 名 (24.6\%)であった。

対象者の性別は概ね女性で316名 (99.2\%)， 年齢は30 40 歳代が263 名 $(82.5 \%)$, 一般学 歴は267 名 $(83.8 \%)$ が高等学校卒業, 看護学歴 は288 名 $(90.4 \%)$ が専門学校卒業であった。 また，所持免許は看護師（保健師・助産師資格 保持者も含む)が306 名 (95.9\%) で, 准看護師 は13 名 $(4.1 \%)$ であった。職位は管理者が56 名 $(17.7 \%)$ ，一般職員が233 名 $(72.9 \%)$ であ り, 勤務形態は常勤が209 名 $(65.4 \%)$, 非常勤 が110 名(34.5\%)で, 1 週間あたりの訪問件 数は11〜20 件がもっとも多く 160 名 $(50.3 \%)$ であった，健康状態は良好とやや良好を合わ せて264 名 (82.8\%) であった。就職の理由と して遣り甲斐と答えた者がもっとも多く 149 名(46.6\%)の者が回答していた。現ステーショ ンでの勤務経験年数は $4.4( \pm 3.5)$ 年 $($ 範囲 0 〜 20 年)で, 看護経験年数は $15.0( \pm 7.0)$ 年(範囲 0 ～40), オンコール当番回数は月に1.2( \pm 2.3$)$ 回(範囲0 28 回), 当番時の出勤回数は6.4 ( 6.6) 回(範囲0〜31 回)であった（Table 1).

2. 訪問看護ステーションの労務管理および業 務内容に関する訪問看護師の評価

訪問看護師は労務管理に関する項目すべて において, 半数以上が肯定的に回答していた。 また訪問看護師の認識している業務内容は,
「ケアに対して充実感がある」と肯定的に答え た者が252 名 $(79.0 \%)$ いる一方で，「学ばない といけないことが多くある」316 名 (99.1\%)， 「判断を必要とする場面が多すぎる」294 名 (92.1\%) と肯定的でない回答をした人が大多 数を占めた（Table 2).

3. 訪問看護の仕事負担感と業務内容の関連 仕事内容は負担が大きいと思うかの設問 に、「そう思う」「どちらかといえばそう思う」

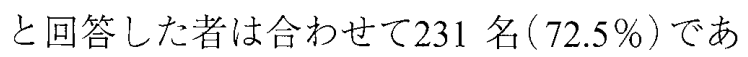
り, 仕事負担感と業務内容との関連では，「仕 事内容は就職前に考えていたことと違う」(負 担が大きい群：2.56, 負担が大きくない群： $2.85, \mathrm{Z}=-2.546, P<0.05)$, 「訪問以外の任さ れている仕事が多すぎる」(負担が大きい群： 2.31 , 負担が大きくない群 : $2.84, Z=-4.261$, $P<0.001)$ ，「判断を必要とする場面が多すぎ る」(負担が大きい群：1.57, 負担が大きくない 群：1.95, $Z=-4.87, P<0.001)$, 「医療処置・複 杂隹な看護技術が多すぎる」(負担が大きい群： 1.92 , 負担が大きくない群: $2.48, \mathrm{Z}=-5.236, P$ <0.001）であり，それぞれの業務内容の項目 について「就職前に考えていた仕事内容との 相違」「任されている仕事の多さ」「判断を必 要とする場面の多さ」「複雑な看護技術の多 さ」を感じている人ほど仕事の負担感を大き いと考えていることが示された。

4. 訪問看護師としての就業継続意向と労務管 理の関連

訪問看護師としての就業継続意向は,「でき るだけ続けたい」「しばらく続けたい」が249

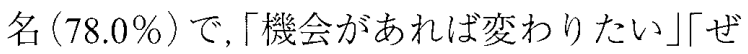
ひ変わりたい」は38名(11.9\%)であった．仕 事の継続意思と労務管理に関する項目との関 連では,「ステーションの将来性があること」 (継続群: 1.93, 非継続群: $2.32, Z=-2.916$, $P<0.01)$, 「人数は足りている」(継続群: 2.26 , 非継続群 : $2.61, \mathrm{Z}=-2.011, P<0.05)$, 「賃金 は仕事に見合っている」(継続群：2.33, 非継 
Table 1. 訪問看護師個人の属性

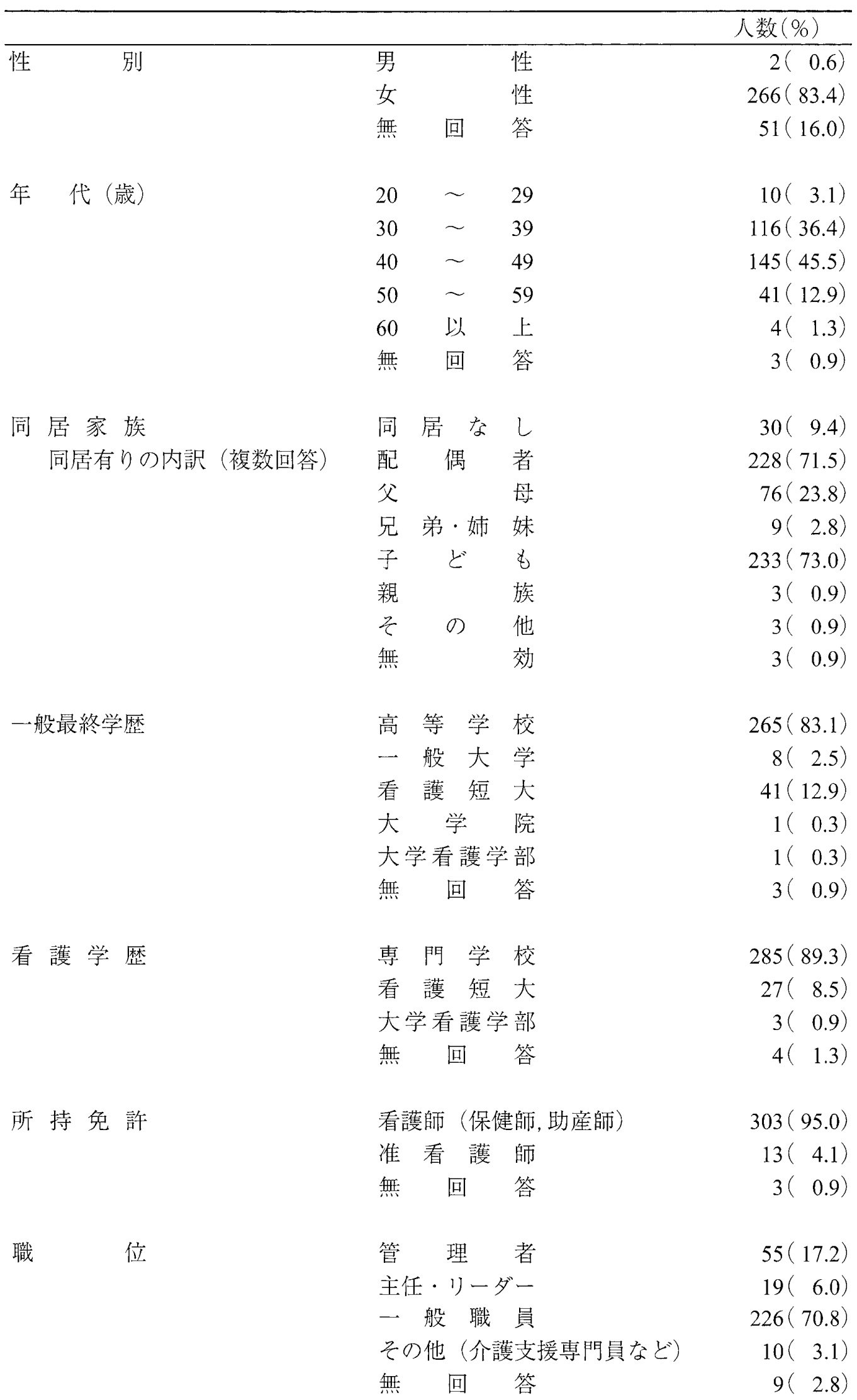


勤 務 形 態

これまでに経験した職場(複数回答)

一週間あたりの訪問件数（件）

昨年度の年収 (万円)

健 康 状態

就業中の事故·病気の保険 (損害·傷害)

訪問看護ステーションへの就職理由

$$
\begin{array}{lll}
\text { 常 } & & \text { 勤 } \\
\text { 非 } & \text { 常 } & \text { 勤 } \\
\text { 無 } & \text { 回 } & \text { 答 }
\end{array}
$$

総 合 病院

病院

診療所

施設

その他（行政, 健診センターなど）

無回答

$\begin{array}{llc}5 & \text { 以 } & \text { 下 } \\ 6 & \sim & 10 \\ 11 & \sim & 20 \\ 21 & \sim & 30 \\ 31 & \text { 以 } & \text { 上 } \\ \text { そ } & \text { の } & \text { 他 } \\ \text { 無 } & \text { 回 } & \text { 答 }\end{array}$

130 以 下

$131 \sim 300$

$301 \sim 400$

$401 \sim 500$

500 以上

無回答

良好

まあ 良好

やや不調

不調

わからない

無回答

カバーされる

カバーされない

不明

無回答

やりがいがあると思った

時間的制約が少ない

身体的負担が軽い

仕事内容に見合った収入が得られる

その他（人事異動など）

無回答
$205(64.3)$

$108(33.9)$

6( 1.9$)$

$213(66.8)$

$173(54.2)$

$71(22.3)$

$35(11.0)$

$27(8.5)$

$5(1.6)$

$34(10.7)$

$75(23.5)$

$157(49.2)$

$41(12.9)$

$3(0.9)$

$2(0.6)$

$7(2.2)$

$63(19.7)$

$82(25.7)$

$71(22.3)$

$58(18.2)$

$13(4.1)$

$32(10.0)$

$99(31.0)$

165 (51.7)

$51(16.0)$

$3(0.9)$

$0(0.0)$

$1(0.3)$

$194(60.8)$

$31(9.7)$

$86(27.0)$

$8(2.5)$

$140(43.9)$

92( 28.8)

10( 3.1$)$

$4(1.3)$

54(16.9)

$\frac{19(6.0)}{N=319}$ 


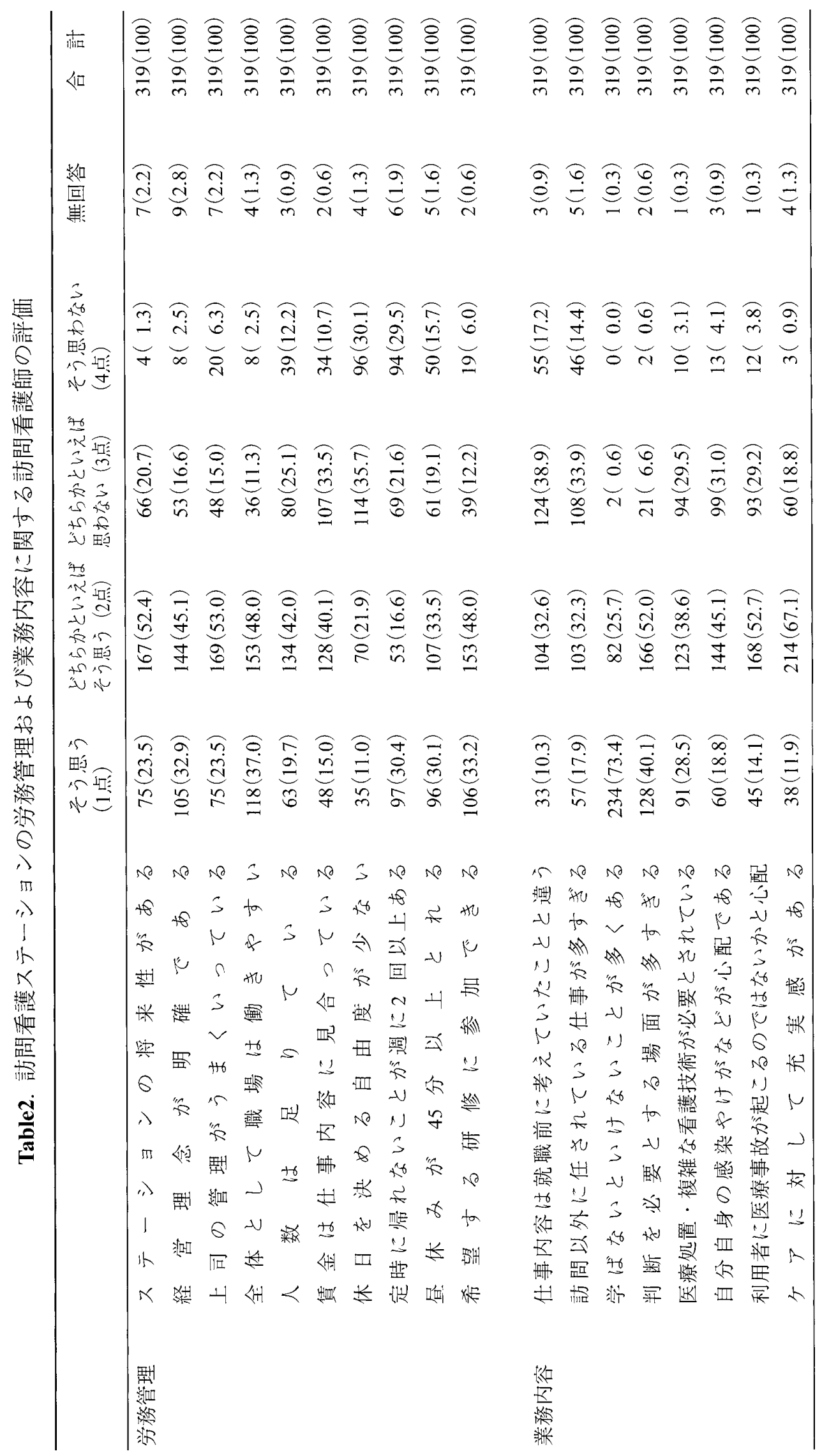


続群：2.92, $\mathrm{Z}=-3.865, P<0.001)$ であり, それ ぞれの労務管理の項目について,「将来性」「人 数」「賃金と仕事内容の関係」に肯定的考えを 持っている人ほど訪問看護の仕事の継続意思 を持っていることが示された。

\section{考察}

\section{1. 対象者の概要}

訪問看護師の属性として年齢・経験年数で は, 本対象訪問看護師の20 歳代は10名(3.1\%) と非常に少なく, その一方で, 30〜40 歳代が 263 名 $(82.5 \%)$ と圧倒的に多いこと, 訪問看護 師としての経験は平均 $4.4( \pm 3.5)$ 年であるが 看護師としての経験は $15.0( \pm 7.0)$ 年と長いこ となどがわかった。この結果は2001 年看護 職員実態調查 [7]による「就業している看護 職員」の $20 \%$ は20 歳代であるとの報告と比 較すると, 訪問看護師の年齢層の特徵を示 すものであるといえ，訪問看護師を対象に 行った畐岡ら [8]の訪問看護師の年齢は, 35 〜 44 歳まで $47.9 \%$ 占め, 訪問看護経験年数 $4.3( \pm 3.0)$ 年, 臨床経験者 $99.4 \%$ であるという 報告と類似した結果を持つことが示された。 所持免許として看護師免許所持者が, 准看護 師免許所持者よりも圧倒的に多いことは，訪 問看護の業務特性である単独での判断・実施 などが求められている現状から納得できる結 果である，また，就職する理由として「遣り 甲斐」を求めて訪問看護をはじめる看護師が 半数近いことが明らかになった。

2. 訪問看護ステーションの労務管理および業 務内容に関する訪問看護師の評価

本対象の訪問看護師は，特に「学ばないとい けないことが多くある」「判断を必要とする 場面が多すぎる」と回签した人が大多数を占 めて抢り, 病院看護の経験を持つ看護師の回 答であることを考慮すると，これまでの経験 に上乗せする訪問看護特有の知識や技術の修 得が必要であると訪問看護師自身が認識して いることが示された。
3. 訪問看護の仕事負担感と業務内容の関連 仕事負担感と業務内容との関連において, 「就職前に考えていた仕事内容との相違」「任 されている仕事の多さ」「判断を必要とする 場面の多さ」「複雑な看護技術の多さ」を感じ ている人ほど, 仕事負担感を持っていること が示された，中でも判断や医療処置に関する ことについて近年の訪問看護では, 在宅医療 の推進のもと重度の障害や医療処置が必要な 利用者が在宅で生活するようになり，ハイテ ク在宅看護の提供が必要とされるようになっ てきている。そのため在宅での使用に適した 特殊な機器類も次々と開発され，その操作・ 管理・指導も訪問看護師が担うことが求めら れるようになってきた。しかし臨床経験があ るとはいえ，それぞれの看護師には有する経 験・知識・技術に差があり，学習準備状態がす べて同じわけではない.そのような状況の中， 業務を遂行していかなければならない訪問看 護師は, 仕事に対して負担感を生じる結果を 招くのではないだろうか。本対象者における 訪問看護師は, 全員が臨床経験者であり, 先行 研究 [8]においても99.4\%が臨床経験者で占 められていた。臨床経験者は, 訪問看護をは じめるとその業務特性にリアリティショック を感じる可能性も否定できない.

4. 訪問看護師としての就業継続意向と労務管 理の関連

訪問看護師の仕事は「できるだけ」「しば らく」を合わせると, 継続したいと考える人が 249 名 $(78.0 \%)$ を占めており, 訪問看護ステー ションで勤務する看護師の多くが訪問看護の 仕事を継続したいと考えていることが明らか になった，訪問看護師としての就業継続意向 と労務管理との関連では,「ステーションの将 来性」「看護師の人数」「賃金と仕事内容の関 係」に肯定感を持っている人ほど, 訪問看護の 仕事を継続して行こうという意思を持ってい ることが示された，訪問看護ステーションに おける労務管理は，そのほとんどを管理者が 行っている，病院勤務では経験することのな 
かった労務管理を看護職が行うことについ て,不慣れであること, 経営感覚の問題などか らさまざまな課題が浮き彫りになっている。 また看護白書によると「訪問看護ステーショ ンは運営上も経営的にも独立した事業所の位 置付けがされているにもかかわらず, 実質的 な裁量権を持たない管理者がいることや賃金 表がない, 法定福利制度が未整備であるなど の訪問看護ステーションも存在している」と いう [9]，そのため,これらのことを考慮し 管理者には労務管理の整備に向けた努力が必 要とされる。また, 訪問看護ステーションの 労務管理は訪問看護師の就業継続意思にかか わってくるものであると管理者は認識するこ とが必要である。

5. 職場環境および体制の整備に向けて

訪問看護師の就業継続意思には訪問看護又 テーション管理者による労務管理が大きなウ エイトを占めていること, 仕事負担感にはリ アリティショックが関係していることが本研 究より明らかになった。訪問看護師の離職率 の低下を目指すならば，これらの訪問看護師 の特徴を踏まえた上で, 環境を整備していく 必要がある。

そのためには，まず管理者は労務管理につ いての意識を高め, 経営感覚や知識を養うた めの「経営管理セミナー」などを活用しステー ションのより良い経営・運党に努める必要が ある。訪問看護ステーションの多くを占める 小規模事業所は, 訪問回数が収入に直結する 事業であるが変則勤務や多様な勤務が可能で ある、訪問看護師の就労意欲とキャリアアッ プについて平成16 年度看護白書では, 時間を 有効に活用できるような労働環境を整備す ることも一案であると提案されている [10]. 休祝日や夜間勤務が不可欠ならば, 休日を決 める際に職員の意見を十分取り入れるシステ ムを導入することなども必要である.

リアリティショックについては, 就職の際 に, 労働条件や仕事内容に関する十分なイン
フォメーションを提供し, 質問や不安に対す る納得できる説明を可能とし, 雇用者と学衝 者の意思の踈通を罒り，看護師が抱いている 訪問看護のイメージと実際の業務の隙間を少 しでも業務開始前に埋めておく努力が必要で ある，そして業務開始後も看護師を支持でき る体制を整え，各々の看護師が必要とする知 識・技術についてボトムアップを意図した体 系的・系統的継続教育の実現を図ることが重 要である。

\section{研究の限 界}

本調査では回収率が $24.6 \%$ と低くまた横断 的研究であるため, 本結果を福岡県内の訪問 看護ステーションおよび訪問看護師の実態と して一般化することはできない，今後は回収 率を高めるための方法論を検討し，また調查 の対象を福岡県のみならず全国レベルまで拡 大した実態調査を行い, 訪問看護ステーショ ンの望ましい労務管理と，それを整備するた めの方策について検討を進めていきたい.

\section{結語}

訪問看護師の仕事負担感や就業継続意思と 訪問看護の業務特性について実態調査を行っ た結果, 以下のことが明らかになった。

1. 訪問看護ステーションに勤務する看護師 は, 訪問看護の経験年数は 5 年未満の者が多 いが, 臨床経験は10 年以上の中堅以上の看護 師が多い，年齢では30４0 歳代がほとんど を占めて扮り,この結果は冨岡ら [11]の行っ た先行研究とも一致した.

2. 訪問看護師は, 自分の働くステーションの 労務管理について概ね肯定的に捉えていた。 業務内容では，「充実感」はあるが，「学ばない といけないことが多くある」「判断を必要と する場面が多すぎるなど, 肯定的でない意見 が多かった。 
3. 訪問看護師は,「就職前に考えていた仕事内 容との相違」「任されている仕事の多さ」「判 断を必要とする場面の多さ」「複雑な看護技 術の多さ」を感じている人ほど, 仕事負担感を 持っていることが明らかになった。

4. 訪問看護師は,「ステーションの将来性」「人 数」「賃金と仕事内容の関係」に肯定感を持つ 人ほど, 訪問看護の仕事の継続意思を持って いることが明らかになった。
5. 訪問看護師の就業継続意欲の向上のための 労務管理として，管理者が労務管理の意識を 高めること, リアリテイショックへの対策と して体系的・系統的継続教育の実現を図る環 境を整えることも一助となることが示唆され た。

\section{引用 文 献}

1. 佐藤美穂子 (2002)：訪問看護の変遙. 訪問看護白書. 財団法人日本訪問看護振興財団, 東京 pp $11-18$

2. 胡 秀英 (2002): 訪問看護ステーションの処遇・労㗢環境. 訪問看護白書. 財団法人日本訪 問看護振興財団, 東京 pp 43-58

3. 阿部俊子 (2004): 看護労働を支える就業意識. 平成16 年版看護白書. 日本看護協会出版会. 東京 pp 91-92

4. 鹿毛美子子, 河井康子, 井上弘子（2002）: 訪問看護師の職務満足度と離職の要因の関連から定 着率促進の方策を検討する。第33 回日本看護学会抄録集2002 看護管理：129

5. Cherniss C (1993): Role of professional self-efficacy in etiology and amelioration of burnout. In W B Schaufeli, C Maslach \& T Marek(ed.) Professional Burnout. Taylor \& Francis Washington, D.C. pp135 149

6. Teri M (1998): A qualitative study of nurses who recently changed from hospital based practice to home health care nursing. Journal of Continuing Education in Nursing 29(2):55-60

7. 照沼則子, 櫻井美鈴 (2004): 看護労働者のライフサイクル特性. 平成16 年版看護白書. 日本 看護協会出版会, 東京 $\mathrm{pp} 78-80$

8. 冨岡小百合, 石澤恵, 大竹まり子, 赤間明子, 佐藤千史, 鈴木育子, 小林淳子, 叶谷由佳 (2007)： 訪問看護の職務満足に関連する要因。日本在宅ヶア学会誌 11(1):43-51

9. 胡 秀英 (2002)：訪問看護ステーションの処遇・労働環境. 訪問看護白書. 財団法人日本訪 問看護振興財団, 東京 $\mathrm{pp} \mathrm{43-58}$

10. 佐藤美穂子 (2004): 訪問看護師の労働実態. 平成 16 年度看護白書. 日本看護協会出版会, 東 京 pp $129-142$

11. 冨岡小百合, 石澤恵, 大竹まり子, 赤間明子, 佐藤千史, 鈴木育子, 小林淳子, 叶谷由佳 $(2007)$ : 訪問看護の職務満足に関連する要因。日本在宅ケア学会誌 11(1)：43-51

12. 上谷いつ子 (2005): S大学病院看護師の仕事の継続意志と職務満足に関する要因．第35 回日 本看護学会論文集 看護管理 $74: 220-222$

13. 田村やよひ (2004): 看護政策の実際。看護教育 45(2)：126-130

14. 内田陽子, 山崎京子 $(2000)$ : 利用者満足度の高い訪問看護ステーションのケア体制の特徵に 関する研究. 日本在宅ケア学会誌 4(1): 94-101 
15. 山崎摩耶, 佐藤美穂子, 田久保恵津子 他（2002）：訪問看護白書. 財団法人日本訪問看護 振興財団, 東京 pp 11-58

16. 杉田美佐子（2003)：チーム作りとステーション管理。訪問看護と介護 8(7)：538-541

17. 大原まゆみ, 丸口ミサマ, 西尾和子, 田中優子, 平井さよ子 (2004): 高度専門病院に勤務する看 護師の定着可能性. 国立看護大学校研究紀要 3(1)：75-82

18. 仁科祐子, 谷垣静子（2005）：訪問看護師の職業ストレスに関する研究. 訪問看護と介護 10 : $840-949$

19. 中谷久恵, 島内節 $(2000)$ : 利用者満足度による在宅ケアマネジメントの評価に関する研究. 日本在宅ケア学会誌 4(1): 39-46

20. 松山洋子 (2000): 訪問看護ステーションに勤務する看護師のストレスの実態. 順天堂医療短 期大学紀要 11:12-23

21. 松本晃子 (2005): 在宅ケアの魅力 看護が生かせる最適の場. Community Care 7(1): 18-19 
Relationships between the Job Characteristics of Home-Visiting Nurses and Their Job-Related Burden and Intention to Continue Working

\author{
Izumi Mitsumoto ${ }^{1}$, Toshiko Matsushita ${ }^{2}$ and Yuko OuRA ${ }^{3}$
}

${ }^{1}$ Division of Clinical Nursing, School of Health Sciences, University of Occupational and Environmental Health, Japan. Yahatanishi-ku, Kitakyushu 807-8555, Japan

${ }^{2}$ Saitama Medical University, Faculty of Health and Medical Care, School of Nursing. Yamane, Hidakashi 350-1241, Japan

${ }^{3}$ Nursing Department, Graduate School of International University of Health and Welfare. Chuo-ku, Fukuoka 810-0072, Japan

Abstract : The purpose of this survey was to clarify the relationship between the job characteristics of visiting nurses, their workload and their intent to continue their work. The self-administered questionnaire survey targeted visiting nurses at a home-visit nursing care agency in Fukuoka prefecture. The results revealed the following points. Nurses who felt that there was "a discrepancy between what they thought their job description would be and the reality," that there was "a lot more work besides visiting homes," that there were "so many situations that require them to make a decision" or that there were "so many complex nursing skills" were more likely to find their workload burdensome. The more positive they felt about "the future prospects of the nursing agency," "the number of nurses at work" or "their wages," the more likely they were to have the intention of working continuously. The survey also suggested that a raised level of labor-management awareness for managers would help improve the incentive to work for visiting nurses, and the realization of systematic continuing education as a proactive measure to alleviate reactions to difficult realities would also help nurses maintain the desire to work continuously.

Key words : home-visiting nurse, job characteristics, job-related burden, intention to continue working.

$$
\text { J UOEH } 30(2): 185-196(2008)
$$

